\title{
PERANCANGAN DAN PEMBUATAN ALAT PEMISAH BUAH MANGGA BERDASARKAN BERAT BERBASIS ARDUINO UNO
}

\author{
Yanuar Ramadhan ${ }^{1}$ \\ Program Studi Teknik Elektro Universitas Panca Marga \\ Email: yanuarpsby24@gmail.com \\ Ira Aprilia ${ }^{1}$ \\ Program Studi Teknik Elektro Universitas Panca Marga \\ Email: ira.aprilia11@upm.ac.id
}

\begin{abstract}
Mango is one of the fruits that thrive in Indonesia. Mango can easily be grown in yards and gardens as a livelihood in the Probolinggo. There are still many systems that use human labor so it takes a relatively longer time to manage. In fact, fruit trade rs, especially for mangoes, generally can not sort the fruit by its size or weight accurately. Because of the condition, a mango separator system was made based on the weight. To measure the weight of the mango, a censor (Load Cell) is needed as a weight censor which is controlled by the Arduino Uno microcontroller. It is aslo used to help the conveyor as a carrier for mangoes moving to the fruit weighing tub. The mango separator using Load Cell sensors has an accuracy rate about $98.48 \%$. Ultrasonic sensors have an accuracy rate about $88.01 \%$. The testing of the mango separator based on the overall weight has an accuracy rate about $70 \%$.
\end{abstract}

Keywords : Arduino Uno, Conveyor, Load Cell, Manalagi Mango, Sort

\begin{abstract}
ABSTRAK: Mangga adalah salah satudari sekian banyak buah yang tumbuh subur diIndonesia. Mangga dapat dengan mudah tumbuh di pekarangan dan di kebun-kebun sebagai mata pencaharian bagi masyarakat probolinggo. Kehidupan sehari-hari masih banyak sistem yang masih mempergunakan tenaga manusia sehingga membutuhkan waktu yang relative lebih lama. Pada kenyataannya para pedagang buah khususnya buah mangga umumnya tidak dapat mensortir buah berdasarkan ukuran atau berat secara teliti dan akurat. Maka dibuatlah sistem alat pemisah buah mangga berdasarkan beratnya. Untuk mengukur berat buah mangga manalagi dibutuhkan sensor (Load Cell) sebagai sensor berat yang di kendalikan oleh mikrokontroller Arduino Uno serta konveyor sebagai pengangkut buah mangga agar bergerak ke bak penimbang buah. Alat pemisah buah mangga menggunakan sensor Load Cell memiliki tingkat akurasi sebesar 98,48\%. Adapun sensor ultrasonik memiliki tingkat akurasi sebesar $88.01 \%$. Dan pengujian alat pemisah buah mangga berdasarkan berat secara keseluruhan memiliki tingkat akurasi sebesar $70 \%$
\end{abstract}

Kata Kunci: Arduino Uno, Buah Mangga Manalagi, Konveyor, Load Cell, Sortir

\section{PENDAHULUAN}

$\mathrm{P}$ robolinggo adalah kota kecil yang berada di pantura Jawa Timur sebagai kota yang terkenal dengan buah mangga manalaginya. Proses penyortiran buah-buahan pada saat ini masih memakai cara konvensional yaitu penggunaan tenaga manusia (manual). Hal ini memiliki kelemahan yaitu penilaian yang masih subjektif dan tidak konsisten terhadap objek buah serta pekerjaan yang dilakukan secara berulang-ulang dapat menyebabkan kejenuhan. Untuk itu diperlukan penerapan sebuah sistem yang dapat melakukan proses pemilahan secara otomatis.

Berdasarkan persoalan tersebut, penulis tertarik untuk membuat perancangan alat pemisah buah mangga dengan pengendali Berbasis Arduino Uno. Alat ini menggunakan sensor load cell sebagai mendeteksi ukuran (berat). Dalam perancangan alat ini penulis menggunakan satu konveyor tapi dengan 2 tempat penampungan yaitu tempat ukuran mangga besar dan ukuran mangga kecil supaya mangga tidak bertumpuk satu sama lain dengan adanya mikrokontroler yang dapat digunakan sebagai pengendali proses.

\section{A. Arduino Uno}

\section{TINJAUAN PUSTAKA}

Arduino Uno merupakan papan mikrokontroler yang memiliki pin input dan output. Arduino Uno memiliki modul yang berguna untuk menunjang kinerja mikrokontroler, cukup dengan menghubungkan Arduino ke komputer hanya dengan kabel data USB atau mensuplai Arduino dengan adaptor DC atau menggunakan baterai untuk menjalankannya.

Untuk memprogram Arduino Uno diperlukan perangkat lunak bernama Arduino IDE, Arduino IDE adalah perangkat lunak yang dipakai untuk membuat kode program yang akan di unggah ke dalam

\footnotetext{
${ }^{1}$ Program Studi Teknik Elektro Universitas Panca Marga
} 
Arduino agar Arduino dapat berjalan sesuai dengan kode program yang dibuat dimana Arduino IDE ditulis dengan menggunakan Java. IDE Arduino terdiri dari : Editor program, Compiler dan

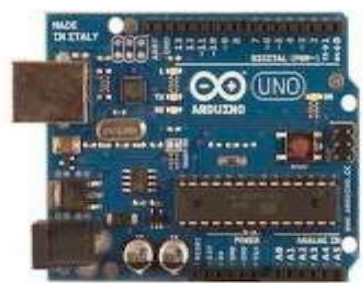

Uploader.[4]

- Gambar 1. Board Arduino Uno

\section{B. Sensor Load Cell}

Sensor Load Cell disini berperan untuk mendeteksi beban atau berat sebuah objek, sensor ini digunakan sebagai perangkat sensor utama pada suatu alat pendeteksi beban seperti timbangan digital. Contoh lainnya diterapkan pada jembatan timbang yang digunakan untuk mencari tahu beban dari sebuah truk pengangkut barang, dan prinsip pengukuran yang dilakukan oleh load cell menggunakan prinsip tekanan.Pada load cell terdapat 4 kabel dengan warna yang berbeda beda yang setiap kabel memiliki fungsinya masing-masing, yaitu kabel merah digunakan sebagaimasukan tegangan atau sumber daya positif ke sensor, kabel hitam digunakan sebagai ground atau sumber daya negatif sensor,kabel hijau sebagai keluaran positif dari sensor dankabel putih sebagai keluaran negatif dari sensor.

Prinsip kerjadari sensor load cell ini adalah memanfaatkan reaksi elastisitas dari logam dari sensor load cell, jika salah satu sisi di dudukan pada penyangga dan sisi lain di beri beban maka akan mengakibatkan gaya dan gaya yang ditimbulkan dari proses itu akan di ubah ke dalam sinyal elektrik oleh pengukur tegangan yang terpasang pada load cell.[6]

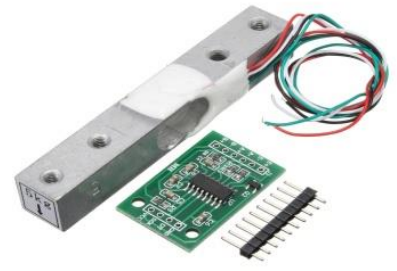

- Gambar 2. Sensor Load Cell.

\section{Relay}

Relay adalah Saklar (Switch) yangdioperasikan secara listrik dan merupakan komponen Electromechanical (Elektromekanikal) yang terdiridari 2 bagian utama yakni Elektromagnet(Coil) dan Mekanikal(seperangkat Kontak Saklar/Switch). Relaymenggunakan Prinsip Elektromagnetik untuk menggerakkan Kontak Saklar sehingga dengan arus listrik yang kecil (low power)dapat menghantarkan listrik yang bertegangan lebih tinggi. Sebagai contoh dengan Relay yang menggunakan Elektromagnet $5 \mathrm{~V}$ dan $50 \mathrm{~mA}$ mampu menggerakan Armature Relay (yang berfungsi sebagai saklarnya) untuk menghantarkan listrik 220V 2A.[3]

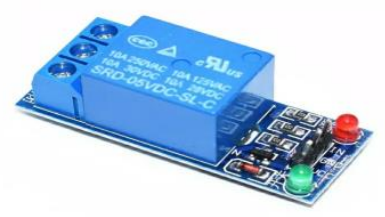

- Gambar 3. Relay 2 Channel

Relay module 2 channel 5V dengan 2 channel output dapatdigunakan sebagai saklar elektronik untuk mengendalikan perangkat listrik yang memerlukan tegangan dan arus yang besar. Kompatible dengan semua mikrokontroler khususnya Arduino. 


\section{Adaptor}

Adaptor i alah sebuah rangkaian yang berguna untukmengubah tegangan AC yang tinggi menjadi DC yang rendah. Adaptor juga disebut sebuah alternatif pengganti dari tegangan DC(seperti baterai,Aki) karena penggunaan tegangan AC lebih lama dan setiap orang dapat menggunakannya . Seperti yang kitatahu bahwa aruslistrik yang kita gunakan di rumah, kantor dll, adalah aruslistrik dari PLN ( Perusahaan Listrik Negara ) yang didistribusikan dalambentuk arus bolak-balik atau AC.

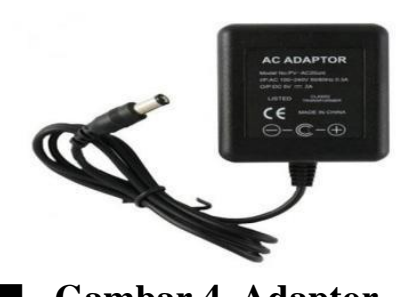

- Gambar 4. Adaptor

\section{E. LCD (Liquid Crystal Display)}

LCD adalah singkatan dari kata (Liquid Crystal Display, yaitupanel penampil yang dibuat daribahan kristalcair. Kristal dengan sifat-sifat khusus yangmenampilkan warna lengkap yang berasal dari efek pantulan/transmisicahaya dengan panjang gelombang dari sudut pengamatan tertentu. Pada dasarnya secara garis besar efek cahaya pada penyususn LCD dapat dideskripsikan sebagai berikut, operasi PDLC (Poliymer Dispersed Liquid Crystal) pada keadaantransparan (Pixel Kiri)dan pada keadaan hamburan (Pixel Kanan).

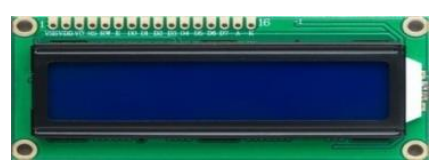

Gambar 5. LCD

Dengan mikrokontroler kita dapatmengendalikan suatu peralatan agar dapat bekerja secara otomatis. Untuk mengakses LCD 20x4 harus melakukan konfigurasipin. Fungsi LCD (Liquid Cristal Display) adalahjenis media tampilan yang menggunakan kristalcair sebagai tampilan suatu data, baik karakter, huruf ataupun grafik. bentuknya tipis, mengeluarkan sedikitpanas, dan memiliki resolusi tinggi. LCD (Liquid Cristal Display) adalah salah satu jenis display elektronik yang dibuat dengan teknologi CMOS logic yang bekerja dengan tidak menghasilkan cahaya tetapi memantulkan cahaya yang ada di sekelilingnya terhadap front-lit atau mentransmisikan cahaya dari back-lit.

\section{F. Sensor Ultrasonik}

Sensor ultrasonik merupakan sensor yang berguna untuk mengubah besaran suara menjadi besaran listrik dan sebaliknya. Cara kerjanya didasarkan pada pantulan suatu atau gelombang suara ultrasonik sehingga dapat dijadikan acuan untuk menghitungjarak suatu benda dengan frekuensi tertentu.Disebut dengan sensor ultrasonik karena sensor ini memanfaatkan gelombang ultrasonik dalam penggunaannya. Gelombang ultrasonik adalah gelombang suara yang berada pada frekuensi yang sangat tinggi hingga $20 \mathrm{KHz}$. Gelombang ultrasonik tidak bisa di dengar oleh telinga manusia. Sensor ini berfungsi sebagai pengirim atau trigger, penerima, dan pengontrol gelombang ultrasonik. Sensor ini difungsikan untukmenghitung jarak benda dari $2 \mathrm{~cm}$ hingga $4 \mathrm{~m}$ dengan tingkat akurasi $3 \mathrm{~mm}$. Sensor ini memiliki 4 pin yaitu pinVcc atau Daya +, Gnd atau Daya -, Trigger, dan Echo. Pin Vcc digunakan untuk listrik masuk positif dan Gnd (Ground) untuk listrik negatif. Pin Trigger digunakan untuk mengeluarkan gelombang ultrasonik dari sensor dan pinEcho untuk menangkap gelombang ultrasonic yangterpantul dari suatu benda

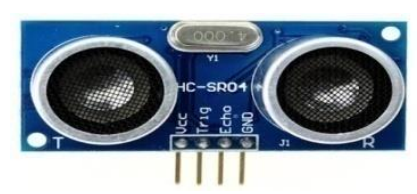

Gambar 6. Sensor Ultrasonik 


\section{G. Motor DC 12v}

Motor adl alat untuk merubah energi listrik menjadi energigerak dan dari energi gerak menjadi energi listrik. Motor DC dapat disebut sebagaimotor arus searah, karena motor ini memiliki dua kutup dan memerlukan arus searah untuk dapat menjalankannya. Motor DC digunakan pada perangkat elektronik dankelistrikan yang menggunakan sumber listrik arus satu arah seperti Lampu DC dan kipas angin DC.

Prinsip kerja Motor DC diantaranya terdapat dua bagian utama yaitu Rotor dan Stator. Bagian yang berputar disebut Rotor, bagian Rotor initerdiri dari kumparan kawat tembaga. Sedangkan bagian motor yang diam disebut Stator, bagianyang diam ini terdiri dari kerangka dan magnet permanen. Pada dasarnya motor DC menggunakan kaidah elektromagnet untuk bergerak, dengan begitu arus listrik dialirkan ke kumparan, kumparan akanmenjadi magnet dan bagian utara akan bergerak ke arah magnet yang berkutub selatan dan kumparan yang bagian selatan akan bergerak ke arah magnetberkutub utara. Karena kutub utara kumparan bertemudengan kutub selatan magnet dan kutub selatan kumparan bertemu dengan kutub utara magnet, maka terjadi gaya tarik menarik yang menyebabkan pergerakan kumparan.

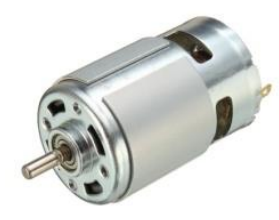

- Gambar 7. Motor DC 12

\section{METODOLOGI PENELITIAN}

A. Blok Diagram

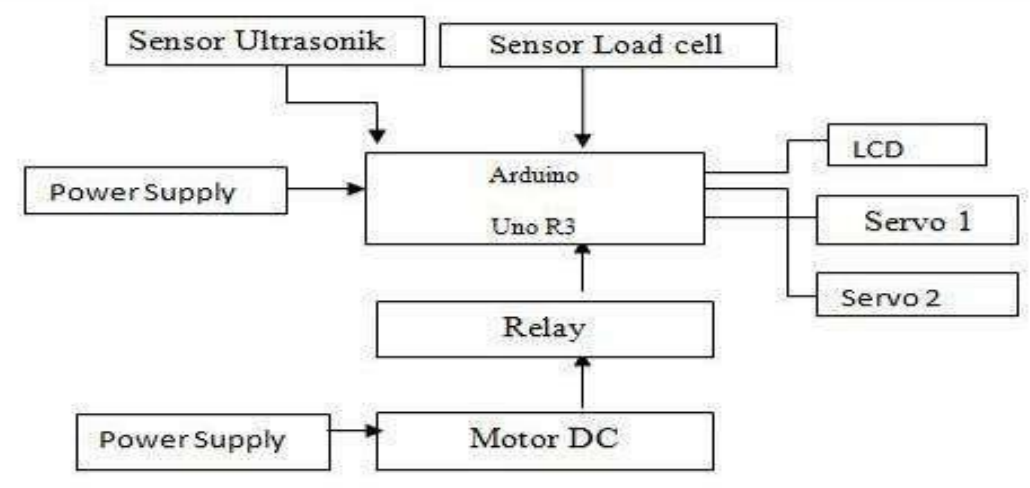

- Gambar 8. Blok Diagram Sistem

Secara garis besar cara kerja sistem dalam :

1 Input perintah yang dilakukan ialah input manual menggunakan perangkat lunak yaitu Arduino Uno.

2 Sensor Load Cell digunakan sebagai sensor timbangan

3 Motor DC sebagai penggerak conveyor buah saat di pindahkan dari tempat satu ke tempat yang lain agar petani tidak perlu menggunakan banyak tenaga dalam memindahkan buah dari pohon ke tempat sortir buah mangga.

4 Dan relay sebagai saklar pemutus saat buah masih proses menimbang di sensor load cell dan otomatis motor DC akan berhenti berjalan.

5 Motor Servo sebagai penggerak pintu timbangan dan pintu pemilah buah.

6 Adaptor sebagai catu daya untuk arduino menjalankan input data 


\section{B. Flowchart Kerja Sistem}

Penelitian ini menggunakan diagram alir (flowchart) untuk membantu proses analisis terhadap pemecahan masalah. Diagram alir (flowchart) merupakan gambaran secara grafik yang terdiri dari simbol-simbol yang menyatakan urutan kegiatan yang dijalani dalam melakukan penelitian. Berikut merupakan diagram alir penelitian :



- Gambar 9. Flowchart Kerja Sistem

Pada awal sistem dijalankan, motor DC sebagai penggerak conveyor akan berjalan dan menjatuhkan buah mangga ke sensor Load Cell dan kemudian sensor membaca berat buah mangga dan nilai hasil berat buah mangga di tampilkan di LCD 16x2, dan kemudian membuka pintu yang dipasangi motor servo satu dan dari hasil nilai berat motor servo dua dan servo akan membaca nilai dari hasil sensor load cell sehingga jika nilai berat $>300$ gram servo dua akan bergerak 90 derajat, jika nilai berat $<300$ gram maka servo dua akan menutup 0 derajat dan buah akan menggelinding ke pintu 2. Setelah itu, sensor Ultrasonic akan mendeteksi buah jika sudah melewati sensor Ultrasonic maka motor DC akan bergerak dan mengulangi cara kerjanya.

\section{Pengujian Alat}

\section{A Rangkaian Keseluruhan Sistem}

Rangkaian keseluruhan sistem merupakan pengujian yang dilakukan setelah semua sistem terkonfigurasi. Konfigurasi tersebut sensor Load Cell sebagai sensor ukur berat, Motor Servo sebagai penggerak pintu, Sensor Ultrasonic sebagai pemberi sinyal saat buah mangga telah melewati pintu pemilah buah dan LCD untuk menampilkan karakter atau tulisan nilai berat. Semua komponen tersebut 
terkonfigurasi dengan Arduino Uno dengan ditanamkan kode program untuk mengendalikan semua komponen tersebut.

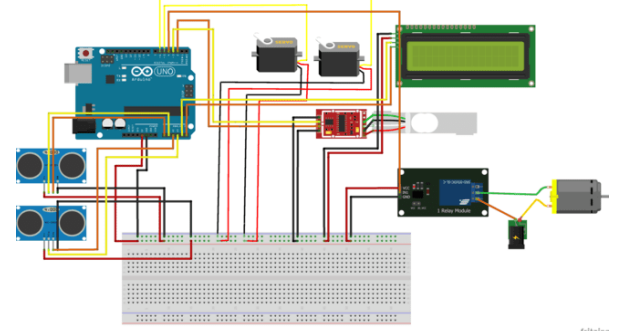

- Gambar 10 : Rangkaian Keseluruhan Sistem

\section{B Pengujian Sistem}

Tahap pengujian dilakukan untuk menentukan hasil pengujian terhadap penyusunan perangkat keras yang digunakan, diantaranya :

\section{Conveyor}

Conveyor merupakan peralatan sederhana yang bergerak dari satu tempat ke tempat lain sebagai alat angkut suatu barang tertentu untuk kapasitas kecil sampai besar. Conveyor digunakan untuk mengangkut buah mangga sehingga para petani buah mangga tidak perlu lagi memindahkan buah mangga dari bak penampungan ke bak pemilahan.

Buah mangga di letakan di atas conveyor secara berurutan kemudian conveyor berjalan ke bak penimbangan berat buah agar diketahui nilai berat buah mangga tersebut.

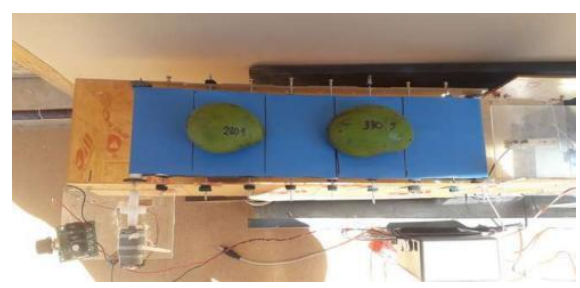

- Gambar 11 : Conveyor saat menampung buah.

\section{$2 \quad$ Relay}

Relay berfungsi sebagai saklar pemutus aliran listrik ke motor DC agar conveyor berhenti saat buah sudah berada di bak penimbang buah. Sehingga buah mangga tidak bertumpuk banyak di bak penimbang. Dan sensor Ultrasonic juga akan mengirimkan sinyal setelah buah mangga melewati sensor Ultrasonic ke modul relay, kemudian relay akan menghidupkan motor DC akan bergerak membawa buah mangga ke bak penimbang.

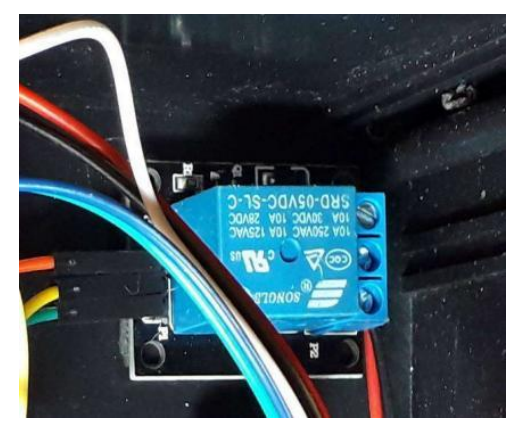

Gambar 12 : Modul relay pada box sistem

\section{$3 \quad$ Pintu Bak Penimbang (Motor Servo 1)}

Pintu pada bak penimbang buah berfungsi sebagai penghalang agar buah mangga tidak jatuh langsung ke tempat bak pemilah buah saat proses penimbangan. Setelah selesai diketahui hasil nilai berat buah mangga, maka pintu motor servo akan membuka agar buah mangga jatuh ke bak pemilah buah yang telah diketahui nilai beratnya. 


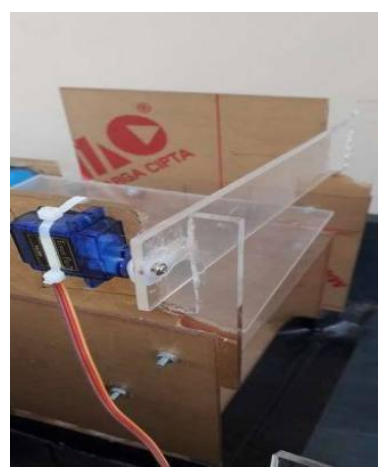

- Gambar 13 Pintu servo pada bak penimbang buah

\section{4}

\section{Pintu Pemilah Buah (Motor Servo 2)}

Pintu pemilah buah berfungsi sebagai pemilah buah mangga saat sensor load cell telah diketahui hasilnya, maka arduino uno akan mengirimkan sinyal ke motor servo sebagai penggerak pintu jika nilai berat diketahui lebih besar dari 300 gram. Dan jika nilai berat diketahui lebih kecil dari 300 gram maka pintu motor servo akan menutup nol derajat.

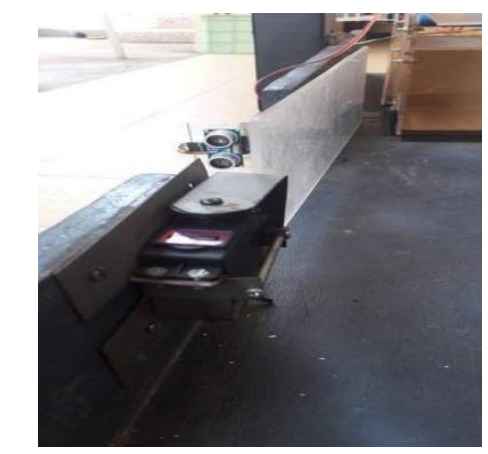

Gambar 14 : Pintu pemilah buah

\section{$5 \quad$ Sensor Ultrasonik}

Ultrasonik disini berfungsi untuk mendeteksi pergerakan apabila buah mangga berhasil melewati pintu maka sensor ultrasonic akan mengirimkan sinyal ke relay agar conveyor (motor DC) berjalan.

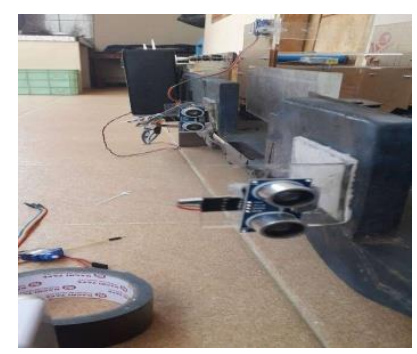

Gambar 15 : Sensor Ultrasonic

\section{Hasil Pengujian}

Pengujian terhadap alat pemisah buah ini dilakukan dengan cara menguji beberapa alat. Pertama, Sensor Load Cell sebagai sensor berat. Kedua, Motor Servo disini ada 2 yakni yang pertama sebagai pintu bak penimbang dan yang kedua sebagai pintu pemisah buah. Ketiga, Sensor Ultrasonik digunakan sebagai trigger saat buah sudah melewati pintu maka sensor ultrasonik akan memberikan sinyal ke relay untuk menghidupkan motor DC. Keempat, LCD digunakan untuk menampilkan tulisan/karakter keterangan informasi perintah yang dijalankan oleh Arduino Uno dan sebagai menampilkan nilai massa buah mangga. 


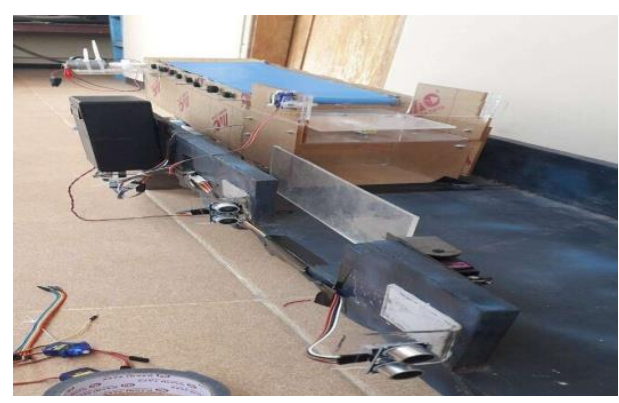

- Gambar 16 : Alat Keseluruhan

Pengujian alat secara keseluruhan dimulai dari di taruhnya buah mangga di atas belt atau sabuk konveyor. Kemudian konveyor berjalan membawa buah mangga ke bak penimbang, setelah itu konveyor otomatis akan mati saat buah sudah proses menimbang. Dan setelah diketahui beratnya pintu bak penimbang akan membuka disusul oleh pintu pemilah. Jika buah mangga beratnya lebih dari 300 gram maka buah mangga tergolong buah besar akan masuk ke pintu 1 dan jika buah mangga kurang dari 300 gram maka akan masuk ke pintu 2. Setelah itu pada pintu 1 dan 2 terpasang sensor ultrasonik yang berguna untuk mentrigger relay untuk menjalankan motor DC.

\section{A Pengujian Pada Buah Mangga Besar}



Gambar 17 : Proses menimbang buah mangga besar

Pada gambar 17 proses dimana menimbang buah mangga dan di peroleh hasilnya.

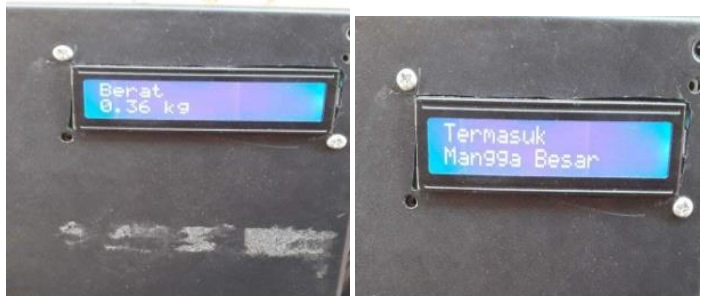

Gambar 18 : Hasil dari proses menimbang buah mangga besar.

Setelah diketahui hasilnya dari gambar 18 maka pintu bak penimbang akan membuka dan pintu pemisah buah (Servo 2) akan membuka.

\section{B Pengujian Pada Buah Mangga Kecil}

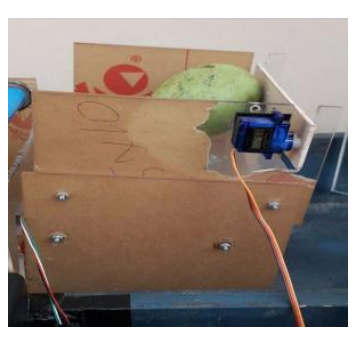

- Gambar 19 Proses menimbang buah mangga kecil 
Pada gambar 19 proses dimana menimbang buah mangga dan di peroleh hasilnya.
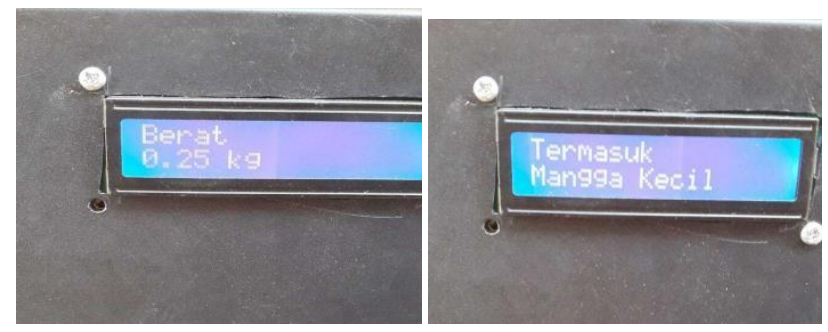

- Gambar 20 Hasil dari proses menimbang buah mangga kecil.

Setelah diketahui hasilnya dari gambar 20 maka pintu bak penimbang akan membuka dan pintu pemisah buah (Servo 2) akan menutup.

- Tabel 1.Perbandingan Sensor Load Cell dengan Timbangan biasa.

\begin{tabular}{c|c|c|c|c}
\hline No & Pengujian & $\begin{array}{c}\text { Timbangan } \\
\text { Biasa }\end{array}$ & Sensor Load Cell & Nilai Eror \\
\hline 1 & Pengujian 1 & 330 Gram & 326 Gram & 4 \\
2 & Pengujian 2 & 370 Gram & 365 Gram & 5 \\
3 & Pengujian 3 & 280 Gram & 276 Gram & 4 \\
4 & Pengujian 4 & 220 Gram & 215 Gram & 5 \\
5 & Pengujian 5 & 320 Gram & 317 Gram & 3 \\
6 & Pengujian 6 & 330 Gram & 324 Gram & 6 \\
7 & Pengujian 7 & 289 Gram & 284 Gram & 5 \\
8 & Pengujian 8 & 267 Gram & 262 Gram & 5 \\
9 & Pengujian 9 & 310 Gram & 305 Gram & 5 \\
10 & Pengujian 10 & 307 Gram & 330 Gram & 4 \\
\hline & & & & 46 \\
\hline
\end{tabular}

Berdasarkan tabel 1 diatas, maka diperoleh persamaan untuk menghitung akurasi sensor Load Cell. Berikut ini merupakan perhitungan akurasi sensor Load Cell :

$$
\begin{aligned}
& \text { Presentase error }=\frac{\text { Nilai Eror }}{\text { Timbangan }} \times 100 \% \\
& =\frac{46 \times 100 \%}{3023} \\
& =1.521 \% \\
& \text { Akurasi Sensor }=100 \%-1.52 \% \\
& =98,48 \%
\end{aligned}
$$

Berdasarkan perhitungan yang dilakukan untuk menghitung akurasi sensor Load Cell sesuai dengan tabel pengujian yang dilakukan terhadap berat buah mangga maka diperole nilai akurasi sensor Load Cell yaitu 98,48\% 


\section{Pengujian Sensor Ultrasonik}

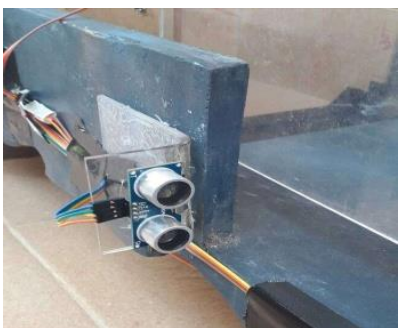

- Gambar 21 Sensor Ultrasonik saat mendeteksi buah lewat.

Pada gambar 21 disini sensor ultrasonik akan mendeteksi buah lewat sehingga mentrigger relay untuk menjalankan motor DC untuk menjalankan konveyor.

- Tabel 2. Data Hasil Pengujian Sensor Ultrasonik

\begin{tabular}{ccc}
\hline No & Nilai Ketentuan $(\mathrm{cm})$ & Nilai Sebenarnya \\
\hline 1 & 12 & 12,32 \\
2 & 12 & 12,22 \\
3 & 12 & 12,14 \\
4 & 12 & 12,21 \\
5 & 12 & 12,20 \\
6 & 12 & 12,18 \\
7 & 12 & 12,26 \\
8 & 12 & 12,44 \\
9 & 12 & 12,43 \\
10 & 12 & 12,16 \\
\hline Jumlah & $\mathbf{1 2 0}$ & $\mathbf{1 4 4 , 3 4}$ \\
\hline
\end{tabular}

$\%$ error $=($ Nilai Sebenarnya - Nilai Ketentuan $) \times 100 \%$

Nilai Ketentuan

$=(144,34-120) \times 100 \%$

120

$=11.99 \%$

Akurasi Sensor $\quad=100 \%-11.99 \%$

$=88,01 \%$

Hasil percobaan pada tabel 2 sensor ultrasonik dengan ketentuan jarak $12 \mathrm{~cm}$ untuk menentukan nilai erornya adalah $11.99 \%$ dan nilai akurasi sensor ultrasonik adalah 88.01 


\section{Pengujian Alat Secara Keseluruhan.}

Tabel 3. Data Hasil Pengujian Pada Alat Pemisah Buah Mangga

\begin{tabular}{c|c|c|c|c|c}
\hline No & Pengujian & Load Cell & Sensor Ultrasonik & Tergolong Buah & Tingkat Keberhasilan \\
\hline 1 & Pengujian 1 & 326 & 12.32 & Besar & Berhasil \\
2 & Pengujian 2 & 365 & 12.22 & Besar & Berhasil \\
3 & Pengujian 3 & 276 & 12.14 & Kecil & Tidak Berhasil \\
4 & Pengujian 4 & 215 & 12.21 & Kecil & Tidak Berhasil \\
5 & Pengujian 5 & 317 & 12.20 & Besar & Berhasil \\
6 & Pengujian 6 & 324 & 12.18 & Besar & Berhasil \\
7 & Pengujian 7 & 284 & 12.26 & Kecil & Berhasil \\
8 & Pengujian 8 & 262 & 12.44 & Kecil & Tidak Berhasil \\
9 & Pengujian 9 & 305 & 12.43 & Besar & Berhasil \\
10 & Pengujian 10 & 303 & 12.16 & Besar & Berhasil \\
\hline
\end{tabular}

Berdasarkan tabel 3 diatas, maka diperoleh perhitungan akurasi pengujian secara keseluruhan ialah :

$$
\begin{aligned}
\text { Presentase error } & =\frac{\text { Nilai error }}{\text { Percobaan }} \\
& =\frac{(10-7)}{10} \times 100 \% \\
& =30 \%
\end{aligned}
$$

Nilai Akurasi Alat

$$
\begin{aligned}
& =100 \%-30 \% \\
& =70 \%
\end{aligned}
$$

Berdasarkan perhitungan akurasi pengujian alat pemisah buah mangga berdasarkan berat sesuai dengan isi tabel maka diperoleh nilai akurasi yaitu $70 \%$

\section{Pembahasan}

Pengujian diatas dilakukan untuk mengetahui tingkat keberhasilan alat pemisah buah mangga berdasarkan berat. Terdapat tiga kegagalan yang terjadi berdasarkan tabel pengujian diatas, dikarenakan buah mangga manalagi memiliki bentuk yang hampir bulat dan sensor ultrasonik pada pintu pemilah kedua tidak mampu mendeteksi buah mangga melewati pintu pemilah kedua dengan keadaan buah berjalan terlalu kencang solusinya dengan mengggunakan sensor PWM agar bisa mengontrol jalan motor DC sebagai penggerak konveyor.

\section{KESIMPULAN}

Berdasarkan hasil penelitian yang diajukan, maka diambil kesimpulan bahwa :

1 Perencanaan dan pembuatan alat pemisah buah mangga berdasarkan berat menggunakan Arduino Uno yang berfungsi untuk mensortasi buah mangga sehingga para petani bisa memilah berat buah mangga saat akan di jual ke pasaran.

2 Sensor Load Cell di fungsikan untuk mendeteksi tekanan berat pada buah mangga, sehingga para petani buah mangga dapat mengetahui berat pada buah saat dalam sortasi. Dan berdasarkan perhitungan yang dilakukan untuk menghitung akurasi sensor Load Cell maka diperoleh nilai akurasi sensor Load Cell yaitu 98,48\%

3 Sensor ultrasonic di fungsikan untuk mendeteksi buah lewat sehingga mentrigger relay untuk menjalankan motor DC untuk menjalankan konveyor. Hasil percobaan pada tabel 2 sensor ultrasonik 
dengan ketentuan jarak $12 \mathrm{~cm}$ untuk menentukan nilai erornya adalah $11.99 \%$ dan nilai akurasi sensor ultrasonik adalah $88.01 \%$.

4 Penggunaan konveyor suatu sistem sistematik yang mempunyai fungsi memindahkan barang dari satu tempat ke tempat yang lain, sebagai contoh di penelitian ini buah mangga sebagai bahan yang di angkut menggunakan konveyor.

\section{Saran}

Penelitian yang telah dilakukan tidak lepas dari kekurangan dan kelemahan, oleh karena itu untuk pengembang sistem lebih lanjut diperlukan perhatian terhadap beberapa hal, diantaranya :

1 Pengembangan selanjutnya tentang sistem perancangan dan pembuatan alat pemisah buah mangga berdasarkan ukuran berat menggunakan Arduino difokuskan ke konveyornya agar diperbaiki dalam hal rancangannya.

2 Pengembangan selanjutnya bisa menggunakan sensor warna buah agar dalam sortasi bisa membedakan buah matang dan masih mentah, dikarenakan petani bisa membedakan dan menjual yang mentah untuk kualitas luar kota atau ekspor sedangkan yang matang untuk pasar lokal.

\section{DAFTAR PUSTAKA}

[1] Astuti, Diah Puji, Tjut Zuraiyah, Andi Chairunas Awaliah. Model Sistem Otomatisasi Sortasi Berdasarkan Ukuran Dan Warna Menggunakan Sensor Ultrasonik Dan TCS300 Berbasis Arduino Uno. Bogor: Program Studi Ilmu Komputer FMIPA Universitas Pakuan. 2017

[2] Al Amin. Perencanaan Dan Pembuatan Alat Pemisah Buah Berdasarkan Ukuran Dengan Pengendali Mikrokontroer ATMEGA 8535, Universitas Negeri Padanng. ISSN 2503-1945. Vol. 3 No.3. 2013.

[3] Handri, W. Prinsip dan Pengaplikasian Relay.2014.

[4] Sokop, Steven Jendri. Trainer Periferal Antarmuka Berbasis Mikrokontroler Arduino Uno. Jurusan Teknik Elektro, Fakultas Teknik, UNSRAT, Manado . vol. 5 No.2 ISSN 2301-8402. 2016.

[5] Tamam, M. Taufiq, Taufiq Dwiono, Johar Arif Wakhyu. Perencanaan Dan Pembuatan Prototype Sistem Sortir Buah Jeruk. Universitas Muhammadiyah Purwokerto. Vol.19, No.1, P-ISSN: 14108607,E-ISSN:2579-9096. 2018.

[6] Wahyudi, Wahyudi, Abdur Rahman, Muhammad Nawawi.. Perbandingan Nilai Ukur Sensor Load Cell Pada Alat Penyortir Buah Otomatis Terhadap Timbangan Manual. Trenggalek Vol 5. No 2.n 2017.

[7] Wicaksono, Mochammad Fajar, Hidayat. Mudah Belajar Mikrokontroler Arduino. ISBN 978-602-6232-50-2. Penerbit INFORMATIKA Bandung.2017. 